\title{
DISCUSSION ON ISSUES OF THE THEORY OF LEGAL INCENTIVES Aleksandr Gavritskiy ${ }^{1}$, Svetlana Miroshnik $^{2}$
}

\begin{abstract}
The purpose of this article is to examine legal incentives as a form of a lawful norm to improve the social actions of individuals. A definition of legal incentive as a variety of legal norms is formulated and the features and principles of an incentivizing legal relationship identified and formulated. The provisions can be viewed as approaches for solving the problems of motivating lawful behavior and for use in analyzing practical problems associated with the theory of law, legal culture, and the rule of law. The concept offered reveals new possibilities for cognition of legal relations that are important for developing the theory of legal norms and the theoretical aspects of the realization of law. The functional approach underlying the research emphasizes the importance of this form of law and promotes the more efficient use of the its potential. The conclusions are relevant for further theoretical studies and the development of a policy by private companies aimed at activating the human factor to increase the productivity of their employees.
\end{abstract}

JEL Classification Numbers: J3; J30; K0; DOI: http://dx.doi.org/10.12955/cbup.v6.1214

Keywords: law, right, legal incentive, motivating law relation, motivating subject, motivated subject, effectiveness of legal regulation.

\section{Introduction}

The current status of social development in Russia creates certain increasing demands on the country's law sciences. The study of law as a system that publicly guarantees human rights, a critical social value for the stable development of social affairs, is becoming more urgent.

One conceivable direction of the social transformations is to use scientific principles to create a system of legal prescriptions that fully reflects the essence of law and achieves a maximum social effect in the interests of the public using various legal means.

The legal science experts have the task of developing and updating the legal means of influencing participants in public affairs and studying the nature of motivation and the motivational mechanisms of legal regulation.

Legal incentives represent the strongest lever of motivational pressure, the most important means of educating modern humans. A legal incentive is, therefore, an effective instrument of public administration, a means of resolving existing economic and social problems.

A rule of law is inconceivable without a highly developed, well-functioning legal system capable of responding to all types of changes in society in a timely manner. The motivating impact of legislation results in an objective pattern of social development, by virtue of which there is an increase in the significance and value of law reinforcement.

Thus, the urgent need to study legal incentives is attributed to the need for a modern legal understanding of the mechanisms of regulation.

\section{The Concept of Legal Incentives}

The formation of a person's character is a complex process of interaction between the person and their environment, primarily the social one. The person's character develops according to a 'spiral' of changes happening, not only in the natural and social sphere, but also within the personality itself.

The behavior of an individual is determined by objective needs. As an expression of the relationship between the person and the conditions of their activity, the need appears in unconscious desires and conscious motives of behavior. In other words, the forms in which the needs manifest are diverse. The initial stage of comprehending the need is expressed as attraction and the next is desire.

The need manifests as an external interest of the person, objectively conditioned by the content of the emerging economic affairs. An interest is a conscious cause and a motive for achieving a person's goals. However, having an interest differs from having a need in terms of perceived importance and emotional attractiveness.

Legal norms and incentives significantly affect the forming of interests and behavior of a person due to their motivational influence

\footnotetext{
${ }^{1}$ Faculty of Law, Rostov Branch of Russian Academy of Justice, Rostov-on-Don, Russia, rapgospd@bk.ru

${ }^{2}$ Faculty of Law, Rostov Branch of Russian Academy of Justice, Rostov-on-Don, Russia, rapgospd@bk.ru
} 
From a functional perspective, the legal incentive is a set of legal norms that establish certain means of influencing the mind and psyche of a person in order to strengthen their motivation for lawful behavior.

The following covers the problem of determining legal incentives based on the characteristics of today's understanding of the law. The delineation of law and acts of law allows one to reconsider how the rule of law relates to the legal norm.

The legal norm has been long known. History has demonstrated that the legal norm consolidates both the legal provisions and the arbitrary rule of the ruling elite. The legal norm is impartial to the essence of the content it establishes. The legal norm, rather than the law, is derived from the state. Law is constantly objective, being a criterion for assessing the content of state activities against the legal ideals of society and the state.

Being a part of law, legal incentives provide a public opportunity for a citizen to satisfy the needs and interests established in the norm of the law by using their subjective right and fulfill their legal obligation or both. Furthermore, they can receive a reward in the form of various tangible goods as a natural consequence of lawful behavior, which exceeds that usually expected.

The award offers a huge potential for accentuating the awareness and will of both individuals and law bodies. This was understood during ancient times. According to Duyvendak (1928), it was noted in the laws of Manu (compiled between the second century BC and the second century AD) that:

It is not praiseworthy to act solely because of the desire for rewards, but independence from such a desire cannot be found in this world: this desire is the basis for the study of Veda and the fulfillment of the actions prescribed by Veda. Here (on earth) there is not a single thing that would have been committed by man free from the desire of reward; everything that man does is the consequence of the desire of reward. (Duyvendak, 1928, p.43)

Legal incentives are specific to those being influenced in terms of both individuals and legal entities. The incentives affect the awareness and psyche of individuals, for example, in regards to the possibility of promotion and collectives, for example, in regards to a public legal opportunity to obtain a grant.

Structurally, legal incentives can be divided into simple and complex. The first group includes the norms regulating the issues of remuneration or encouragement. They are the structural elements of all other legal incentives. In other words, a simple legal incentive is a separate legal norm that establishes positive means of influencing an individual's mind and psyche.

Complex legal incentives are a combination of simple incentives that complement each other and enhance the effect on the motivated subject. For example, a legal incentive for a taxpayer in tax law is a special way of interrelating the legal norms governing the implementation of tax control. Others include the provision of tax incentives and the norms that establish a scientifically sound tax burden. Another is an interconnection that creates a legal regime to encourage actions in the interests of the individual, society, and the state.

Legal incentives comprise two categories by the nature of legal consequences, namely, absolute (mandatory) and relative (probable). The basis for this classification is the nature of the positive sanction of this legal norm, that is, the probable or inevitable receipt of a reward. For example, the possibility of receiving a state award is a relative legal incentive. Allowances and additional payment for working at night are absolute incentives, since the employer's obligation to provide these payments are subject to certain conditions as legislated.

\section{Legal Affairs with Incentives}

A legal relationship is a form of expressing an existence in law. There are social relations that can exist only as legal relationships.

Budget, tax, and certain other affairs have an exclusively legal form. They start solely by the will of the legislator who models each in time to engage a new 'creation'.

Accordingly, they involve the following:

- Social relations being developed in society and requiring the acquisition of a legal form to ensure law and order;

- Social relations that form legal relationships only after the adoption of relevant legal norms and their implementation. 
Therefore, it is unlikely to be appropriate to formulate a universal definition of a legal relationship. Legal affairs arising as a result of the effect of the legal norm on public and legal affairs, as a means of regulating social relations, are different in nature and do not merge as one. The first group of legal affairs is a form of interaction between society and lawmakers, while the second reflects the state sovereignty in public affairs.

A legal affair with incentives requires a certain form of social interaction, the emergence of which depends entirely on the initiative of all participants. In this sense, the public's attitude, regulated by legal incentives, is a result of the interaction of its parties. The process of interaction and its development occurs on the basis of mutual expectations of each side of the behavior in terms of certain criteria.

Individuals enter into a legal relationship that motivates them to achieve certain results, e.g., socially significant consequences. Lawmakers aim to increase social and civic activity by legislating a means of positively influencing people's awareness and psyche.

Individuals and legal entities, entering legal relationships that motivate, strive for moral and material benefits envisaged by general and local normative legal acts to change their social status and satisfy their vital needs.

However, they are not obliged to use the legal approach to achieve their goals. Entry into such a legal relationship is the manifestation of their private will.

This legal relationship is established between equal independent parties from a legal perspective. First, this 'equality' means that each party has equal rights and obligations. Therefore, the parties have equal opportunities at all times to develop or terminate this type of legal relationship. In the case of a unilateral termination of the relationship, the initiator is likely to experience unfavorable consequences.

Second, the equality of parties means that both need to agree equally on establishing such a relationship. Lawmakers independently decide on the need to legislate incentives as tools of influence. Individuals and legal entities can freely enter into or opt out of a legal relationship with incentives at any stage of its development.

The following characteristics are intrinsic of a legal relationship with incentives:

1. Develops between people and results from their conscious actions.

2. Arises, changes, or terminates entirely on the basis of legal incentives. Legal incentives are generated and directly realized through these types of legal relationships.

3. The parties involved hold subjective rights and legal obligations. The basis of subjective law is a legally enforceable opportunity; the basis of duty is a legally enforceable necessity. The bearer of the possibility is called the empowered, the bearer of the obligation is called the liable. The former can perform certain actions; the latter is obliged to execute them.

4. Supports individualism, which defines the participants and determines the measure of their lawful behavior.

5. Unwavering in that a legal incentive containing only the intention of lawmaker is insufficient reason for its existence. The main requirement is the manifestation of the will of both its participants since this type of relationship is realized, primarily, through the awareness of each person.

6. Especially protected by the state, which is directly interested in its 'frequent' recurrence.

This type of relationship is a form of public affairs that uses legal incentives with motivated and motivating entities holding subjective rights and legal obligations. Thus, the term incentivized legal relationships is defined.

This type of legal relationship has a certain traditional structure that includes three elements: subjects, objects, and content.

The range of 'subjects' of legal relationships that offer incentives is extensive. Depending on the legal possibilities and the target orientation, they can be subdivided into motivating and motivated 'subjects'.

Motivating 'subjects' are persons with legal personality. Individuals, collectives (organizations, and public and local authorities), public and legal entities, and 'subjects' of international law fall into this 
category.

The range of motivated 'subjects' is broader. The entry into a legal relationship for motivational reasons does not require a 'legal personality'.

A legal personality traditionally includes legal and functional capacities, which are both generally and specifically related to each other. An individual can act as a motivated 'subject' if they have legal capacity. In certain cases, differences in functional capacity will not influence the legal relationship. This can be expressed in two ways:

1. The implementation of legal incentives in terms of the future. The defining characteristics are that the person receiving the relevant information forms an ideal model of behavior in the future and determines a goal conditioned by their needs and interests.

2. The person who does not have functional capacity may act as the subject of an incentivizing legal relationship in cases established by law.

The incentivizing legal relationship has a certain 'object'. The question of the object of legal affairs remains a highly contentious issue in the theory of state and law.

One thought is that an object of legal affairs, particularly one with incentives, needs to have the ability to directly perceive the impact of the legal norms. Therefore, physical or moral objects would not be objects of incentivized legal relationships because they are outside the regulated public affairs and result from actions of individuals, who are the 'subjects' of legal incentives.

When determining the range of objects that motivate in legal affairs, it is important to note that the behavior of a 'subject' includes the two interrelated types: the somatic and the psychological. Legal norms affect the behavior of a person indirectly. Consequently, legal incentives affect the awareness and the will of the person and this determines their behavior.

A purposeful and practical action proceeding under the influence of legal incentives on the awareness of a person regulates the relationship.

Awareness supports two vital outcomes in that it allows individuals to reflect and then transform their world. Before revealing their personal attributes, the individuals first change their perceptions, understanding, and will concerning their surrounding world. They develop an ideal model of behavior from assessing the content of legal incentives, taking into account the established practice, and identifying the benefits likely to affect them. The plan 'in the mind' results in tangible outcomes. The content of the incentivizing legal relationship is realized in the behavior of the motivated person. The goal of the motivating 'subject' is achieved.

Thus, the object of the incentivizing legal relationship is the awareness of the motivated person.

In most cases, the incentivized relationship is steadfast. To implement legal incentives, a 'common will', as characterized by the coincidence of the legislator's will and the will of participants in public affairs, is needed. Only in this case is the model of ideal behavior incorporated into legal incentives with adequate reflection in the behavior of the person.

Another debatable issue in the theory of legal incentives is the question of determining the content of incentivized legal relationships. Most scientists distinguish material from legal content. The material content comprises social affairs that are regulated by law. Legal content is formed by subjective rights and obligations of participants in legal affairs.

Subjective law and legal obligation establish a measure of legal freedom. The subjective law is the type and measure of a person's possible behavior guaranteed by law. It includes the following:

- An opportunity to independently exercise their rights (for example, rights as an owner of property);

- An opportunity to require appropriate behavior of a liable other; and

- An opportunity to apply to the competent state bodies for the protection of their rights.

A legal obligation is a type and measure of due behavior as defined by law. The structure of legal duty is the reverse of the structure of subjective law.

The content of incentivized legal relationships as a variety of legal affairs is a complexity of rights and duties of motivated and motivating 'subjects'. Subjective rights and legal obligations are specific legal models that are followed by 'subjects' in their implementation and realization. 
Legal incentives, as legal norms, aim to develop a person's socially active behavior. Receiving a particular material or moral benefit becomes a consequence of a lawful act. In some cases, the motivating 'subject' independently solves the problem of recognizing the merits of the motivated 'subject'. A person cannot demand rewards or appropriation of state awards or state or international prizes. The award will 'find its hero'. Normative legal acts determine the powers of the motivating entities for the legal recognition of merits expressed in the official recognition of the socially useful nature of the conduct. Its exceeding effectiveness and the need to express its gratitude to the person is in the form of a reward, namely, a moral, material, or social benefit.

Thus, the basis of legal incentives that generate incentivized legal relationships is a certain identity built on the principle of rewarding 'good for good'. As von Jhering $(1915, \mathrm{p} .22)$ noted: "The social organization of retaliation is a civil phenomenon, while we meet the organization of retribution for the social evil in criminal justice, the state, public opinion and history take part in the retribution for the social good".

Incentivized legal relationships, from the view of legally consolidating the principle of retribution using 'good for good' can be divided into absolute and relative means.

'Subjects' of absolute type of incentivized legal relationships can independently choose the legal recognition of the merits of the motivated person.

Both motivating and motivated 'subjects' are defined in the framework of the relative type of incentivized legal relationships. However, in this case, the motivating 'subject' has the opportunity of determining the award where regulatory-specific conditions are met. The right of the motivated subject is correlated with the corresponding duty of the motivating subject.

Legal relationships, in particular those with incentives, are highly dynamic phenomena as they arise, change, and cease to exist. The dynamics of legal affairs are related to practical life circumstances that are termed 'legal facts' in law science.

Legal facts, as grounds for the emergence, change, or termination of incentivized legal relationships, would require certain characteristics:

- Be specific and expressed publicly;

- Contain information on the condition and dynamics of the public affairs regulated by law;

- Legislated on the hypotheses of legal incentives;

- Generate legal consequences stipulated by the legislator in the form of moral and material benefits for the person.

The main functions of such legal facts are to ensure the emergence, change, or termination of incentivized legal relationships. These support the transitioning of a person's behavior into the ideal model incorporated in the legal incentives.

Legal facts are divided into events and actions by the nature of communication with the individual and the will of participants in the legal relationship. Events are legal facts that give rise to certain legal consequences for a person. In contrast, actions are legal facts that depend on the will of person and are committed consciously. They can be either lawful or unlawful.

\section{Principles of Legal Incentives}

The effectiveness of the impact of legal incentives largely depends on a clear legislative consolidation of the principles of legal incentives. The basic requirements for forming the mechanism of legal regulation are the recognition and implementation of three basic ideas.

First, the unity of legal incentives is expressed in the presence of a single legal framework for recognizing the merits of a person (clear, consistent, and stable 'rules of the game' of motivating and motivated subjects).

Second, the soundness of legal incentives reflects the content of many monuments of law. In particular, according to Duyvendak (1928), the book of Lord shang (shang jun shu) notes that:

All privileges and salaries, bureaucratic posts and ranks of nobility should be given only for service in the army, there should be no other ways. In this way, the one can squeeze all the knowledge, the whole strength of their muscles and make them risk their lives for the sake of the ruler - from the intelligent and stupid, the noble and a commoner, the brave and coward, the worthy and worthless - from each of them. And then eminent people, capable and worthy, 
will go behind them from the celestial empire, like streams of water. Therefore, the army (of such a governor) will have no peers and all the celestial empire will begin to listen to his orders. (Duyvendak, 1928, p.71)

Third, the complexity of legal incentives is reflected in the legal consolidation of a variety of legal incentives, the systemic impact of which can significantly enhance the positive and motivational impact of law. The publicity and attribution of legal incentives makes it possible to strengthen the educational impact of legal incentives.

Notably, there is no universal legal incentive because an incentive for one person may fail to motivate another. A specific system of legal incentives would need to be developed for each individual person or group of people with similar primary needs. Each legal incentive would need to be aimed at meeting the social needs of the individual.

\section{Conclusion}

Legal motivation, by means of legal incentives, has a purposeful effect on the psyche of individuals. Legal actions are the only legal facts in generating incentivize legal relationships. Legitimate actions are classed as either legal acts or legal actions. Legal acts are actions performed with the desire to generate certain positive legal consequences. Such actions can only be carried out by persons with legal capacity. Legal acts lead to legal consequences regardless of the intentions of the person committing the act. Therefore, legal actions are carried out by persons capable or legally incompetent. Thus, the grounds for the emergence, change, or termination of incentivize legal relationships are legal facts that are a class of lawful action. These relationships combine legal incentives with genuine social affairs, and thus, exert a significant influence on the dynamics of social development. The value of a legal incentive is its content, since this legal instrument contributes to a person choosing their best behavior, forming a mechanism of self-regulation. In principle, a legal incentive cannot be violated. It contains positive prescriptions, the implementation of which is embraced by those who aim to motivate others. However, whether a legal incentive is used or not it depends on the specific person. They can either become a party to these legal affairs or remain a passive observer. A legal incentive is one that generates desire, the legal entity's desire to act in such a way as to receive a corresponding reward, which is a legislatively established physical or moral benefit of particular value to the person in question.

\section{References}

Duyvendak, J.J.L. (1928). The Book of Lord Shang: A Classic of the Chinese School of Law / Tr. from the Chinese with Introd. and Notes

von Jhering R. (1915). Der Kampf um's Recht. http://en.wikisource.org/wiki/The_Struggle_for_Law/ 